\title{
PENGARUH PEMBERIAN JUS DAUN UBI JALAR (Ipomoea batatas $($ L. $)$ Lam) TERHADAP KADAR KOLESTEROL TOTAL TIKUS WISTAR JANTAN (Rattus norvegicus) YANG DIBERI PAKAN TINGGI LEMAK
}

\author{
Nidya Witosari, Nurmasari Widyastuti* \\ Program Studi Ilmu Gizi Fakultas Kedokteran Universitas Diponegoro \\ Jl.Dr.Sutomo No.18, Semarang, Telp (024) 8453708, Email : gizifk@undip.ac.id
}

\begin{abstract}
Background: The increase in total cholesterol levels increase the risk of cardiovascular disease. Sweet potato leaves is a food that contains polyphenols, flavonoids, quercetin, tannins, and fiber that effectively lower total cholesterol levels. This study aims to analyze the effect of sweet potato leaves juice on serum total cholesterol levels of rats fed a high-fat diet.

Methods: An experimental study with pre-post test carried out on 12 male Wistar rats (Rattus norvegicus) fed a high-fat, which are grouped into 2 groups: 1 group and the control group were given juice 1 sweet potato leaves. Dose based on levels of quercetin that is equal to $2 \mathrm{mg} / \mathrm{kg}$. Quercetin levels of sweet potato leaf juice was analyzed in order to obtain a dose of $0.006 \mathrm{ml} / 200 \mathrm{~g}$ weight / day. Sweet potato leaf juice is given for 14 days by way of on the sonde. Serum total cholesterol was determined by CHOD-PAP method. Data were analyzed by paired t-test, independent t-test, Willcoxon test, and Mann-Whitney test.

Results: Sweet potato leaf juice can lower total serum cholesterol levels. The mean reduction in total cholesterol of $6.22 \mathrm{mg} / \mathrm{dl}$. The mean total cholesterol level of control group increased by $3.54 \mathrm{mg} / \mathrm{dl}$. There is no significant difference $(p>0.05)$ in the change in total cholesterol levels

Conclusions: Sweet potato leaf juice of $0.006 \mathrm{ml} / 200 \mathrm{~g}$ weight / day for 14 days can lower serum total cholesterol levels in rats fed a high-fat diet.

Key words: sweetpotato leaves; total cholesterol; high fat diet
\end{abstract}

\begin{abstract}
ABSTRAK
Latar Belakang: Peningkatan kadar kolesterol total meningkatkan resiko terjadinya penyakit kardiovaskuler. Daun ubi jalar merupakan bahan makanan yang mengandung polifenol, flavonoid, quercetin, tanin, dan serat yang efektif menurunkan kadar kolesterol total. Penelitian ini bertujuan untuk menganalisis pengaruh pemberian jus daun ubi jalar terhadap kadar kolesterol total serum tikus yang diberi pakan tinggi lemak.

Metoda: Penelitian eksperimental dengan pre-post test dilakukan pada 12 tikus wistar jantan (Rattus norvegicus) yang diberi pakan tinggi lemak yang dikelompokkan menjadi 2 kelompok yaitu: 1 kelompok kontrol dan 1 kelompok yang diberikan jus daun ubi jalar. Dosis berdasarkan kadar quercetin yaitu sebesar $2 \mathrm{mg} / \mathrm{kgBB}$. Kadar quercetin jus daun ubi jalar dianalisis sehingga diperoleh dosis sebesar $0.006 \mathrm{ml} / \mathrm{gBB}$ tikus/ hari. Jus daun ubi jalar diberikan selama 14 hari dengan cara di sonde. Kadar kolesterol total serum ditentukan melalui metode CHODPAP. Data dianalisis dengan paired t-test, independent t-test, uji Willcoxon, dan uji Mann-Whitney.

Hasil: Pemberian jus daun ubi jalar mampu menurunkan kadar kolesterol total serum. Rerata penurunan kadar kolesterol total sebesar 6,22 mg/dl. Rerata kadar kolesterol total kelompok kontrol mengalami peningkatan sebesar $3,54 \mathrm{mg} / \mathrm{dl}$. Tidak ada perbedaan yang signifikan ( $\mathrm{p}>0.05$ ) pada perubahan kadar kolesterol total

Kesimpulan: Pemberian jus daun ubi jalar sebesar $0.006 \mathrm{ml} / \mathrm{gBB}$ /hari selama 14 hari dapat menurunkan kadar serum kolesterol total pada tikus yang diberi pakan tinggi lemak
\end{abstract}

Kata kunci : jus daun ubi jalar; kolesterol total; pakan tinggi lemak

\section{PENDAHULUAN}

Hiperkolesterolemia adalah suatu keadaan terjadinya peningkatan kadar kolesterol di dalam darah. ${ }^{1}$ Hal ini merupakan faktor risiko terkuat terjadinya penyakit kardiovaskuler. ${ }^{2}$ Menurut World Health Organization (WHO) peningkatan kadar kolesterol total dapat meningkatkan risiko penyakit jantung dan stroke. WHO melaporkan sebanyak 2,6 juta atau sekitar 30\% kematian tiap tahun di dunia disebabkan oleh penyakit jantung koroner. ${ }^{3}$ Hasil Riset Kesehatan Dasar tahun 2007
(Riskesdas) menunjukkan prevalensi penyakit jantung koroner di Indonesia sebesar 7,2\%. ${ }^{4}$

Berdasarkan United States Preventive

Service Task Force (USPSTF) membuktikan bahwa pemeriksaan profil lipid dapat mengidentifikasikan penduduk yang berisiko mengalami penyakit jantung koroner. Hasil pemeriksaan terhadap kadar kolesterol total berdasarkan Riskesdas 2013 menunjukkan proporsi penduduk $\geq 15$ tahun dengan kadar kolesterol abnormal sebesar $35.9 \%$. Penggolongan abnormalitas kadar kolesterol total merujuk pada 
National Cholesterol Education Program - Adult Treatment Panel III (NCEP ATP III) yaitu gabungan antara kategori borderline $(200-239$ $\mathrm{mg} / \mathrm{dl}$ ) dan tinggi $(\geq 240 \mathrm{mg} / \mathrm{dl}){ }^{5}$

Salah satu jenis sayuran yang berperan dalam menurunkan kadar kolesterol total darah adalah daun ubi jalar. Daun ubi jalar selain mengandung vitamin, mineral, dan serat juga kaya akan antioksidan yang berperan dalam penurunan kadar kolesterol total .6,8,9 Antioksidan yang berperan adalah golongan senyawa fenolik dan flavonoid. ${ }^{7}$ Zat aktif polifenol dan flavonoid tersebut memiliki berbagai manfaat seperti sebagai antioksidan, antimutagenik, antiinflamasi, dan antikarsinogenik. ${ }^{9}$ Polifenol dan quercetin pada daun ubi jalar menurunkan penyerapan kolesterol dengan cara berikatan pada cholesterol carriers saat melewati membran brush border serta penurunan sekresi apoB yang menyebabkan penurunan produksi lipoprotein..$^{0}$ Pada penelitian sebelumnya pemberian ekstrak air daun ubi jalar ungu mampu menurunkan kadar kolesterol total secara bermakna pada tikus yang diberi pakan tinggi kolesterol. ${ }^{11}$ Penelitian lain juga menyebutkan bahwa pemberian ekstrak flavonoid dari daun ubi jalar dapat menurunkan kadar kolesterol total. ${ }^{12}$

Hal tersebut mendorong peneliti untuk melakukan penelitian mengenai pengaruh pemberian jus daun ubi jalar terhadap kadar kolesterol total darah tikus wistar jantan yang diberi pakan tinggi lemak. Hewan coba yang akan digunakan adalah tikus wistar jantan. Tikus wistar jantan dipilih karena lebih tahan terhadap perlakuan dan tidak mudah stres jika dibandingkan dengan mencit. ${ }^{11}$ Penelitian ini bertujuan untuk mengetahui perbedaan kadar kolesterol total antara kelompok kontrol dengan kelompok perlakuan serta mengetahui perbedaan kadar kolesterol total sebelum dan setelah pemberian jus daun ubi jalar pada tikus wistar jantan yang diberi pakan tinggi lemak.

\section{METODE PENELITIAN}

Penelitian ini dilaksanakan di Laboratorium Fisiologi Hewan, Jurusan Biologi, Fakultas MIPA, Universitas Negeri Semarang pada bulan Juni 2014 hingga Juli 2014. Penelitian ini merupakan penelitian true experimental dengan rancangan pre-post grup design. Variabel bebas dalam penelitian ini adalah pemberian jus daun ubi jalar, sementara variabel terikat adalah kadar kolesterol total.

Subjek penelitian merupakan tikus galur wistar jantan (Rattus norvegicus) yang didapatkan dari Laboratorium Fisiologi Hewan Universitas Negeri Semarang. Kriteria inklusi subjek penelitian adalah berat badan $150-200$ gram dan berusia $8-$ 12 minggu. Kriteria eksklusi adalah tikus mengalami penurunan berat badan sebesar $10 \%$ dari berat badan per minggu, tikus mengalami perubahan perilaku (sakit dan kehilangan nafsu makan) dan tikus mati saat penelitian berlangsung.

Jumlah sampel penelitian menggunakan ketentuan WHO, dimana jumlah minimal subjek penelitian untuk tiap kelompok adalah sebanyak 5 ekor. ${ }^{13}$ Pada penelitian ini terdapat dua kelompok yaitu kelompok kontrol dan kelompok perlakuan, sehingga jumlah sampel keseluruhan yang dibutuhkan sebanyak 10 ekor. Untuk mengantisipasi adanya drop-out maka jumlah sampel tiap kelompok ditambah menjadi 6 ekor, sehingga jumlah sampel keseluruhan yang dibutuhkan yaitu sebanyak 12 ekor.

Pakan yang digunakan selama penelitian berlangsung meliputi pakan standar, kuning telur bebek sebagai pakan tinggi lemak, dan jus daun ubi jalar. Pakan standar yang digunakan adalah jenis BR-2 Comfeed mengandung protein kasar 19\% dan lemak kasar 5\% dengan aquadest sebanyak 12 gram/200g BB/hari. ${ }^{14}$ Pakan tinggi lemak adalah pakan standar ditambah kuning telur bebek yang mengandung 17 gram protein, 35 gram lemak, $884 \mathrm{mg} / 100$ gr kolesterol sebanyak 2 $\mathrm{ml} / 200 \mathrm{gBB} /$ hari. $^{15,16}$

Proses pembuatan jus daun ubi jalar : daun ubi jalar yang digunakan yaitu daun ubi jalar berwarna hijau. Langkah pertama dalam pembuatan jus daun ubi jalar adalah daun ubi jalar segar berwarna hijau yang telah disortasi, ditimbang sebanyak 100 gram, kemudian dicuci pada air yang mengalir. Daun direbus dengan air sebanyak $100 \mathrm{ml}$ selama 5 menit dengan api sedang. Daun ubi jalar yang sudah matang beserta air rebusannya kemudian diblender dengan kecepatan tinggi selama 15 - 20 detik. Jus daun ubi jalar dianalisis kadar quercetinnya terlebih dahulu untuk memperoleh dosis jus daun ubi jalar yang memiliki kandungan setara dengan $2 \mathrm{mg} / \mathrm{kgBB}$ quercetin. ${ }^{17}$

Uji kandungan quercetin jus daun ubi jalar dilakukan di UPT Laboratorium Teknologi Pangan Universitas Katholik Soegijapranata dengan metode spektofotometri. Jus daun ubi jalar ditimbang terlebih dahulu, penimbangan dilakukan agar jus homogen, kemudian dilakukan analisis quercetin yaitu larutan encer $(1 \mathrm{ml})$ yang mengandung flavonoid, $5 \%(\mathrm{w} / \mathrm{w}) \mathrm{NaNO}_{2}(0,7 \mathrm{ml})$ dan 30\% (v/v) etanol $(10 \mathrm{ml})$ dikocok selama 5 menit, kemudian ditambahkan $10 \% \mathrm{AlCl}_{3}$ (w/w 0,7 
ml) lalu semua bahan dikocok selama 6 menit. Setelah 6 menit, tambahkan $1 \mathrm{~mol} / \mathrm{L} \mathrm{NaOH}(5 \mathrm{ml})$. Larutan tersebut kemudian dilarutkan ke dalam 25 $\mathrm{ml}$ etanol 30\% (v/v). Setelah didiamkan selama 10 menit, absorbansi larutan diukur menggunakan spektofotometer. Curva standar diplot menggunakan quercetin sebagai standar. Perbedaan konsentrasi quercetin menggunakan $80 \%$ etanol dan absorbansinya dihitung pada 430 $\mathrm{nm}$ menggunakan spektofotometer. Hasilnya menunjukkan mg quercetin/g berat kering. Setelah dilakukan analisis, diperoleh hasil dalam $100 \mathrm{ml}$ jus daun ubi jalar mengandung sebanyak 32,296 mg quercetin dalam $100 \mathrm{~g}$ daun ubi jalar, sehingga dosis jus daun ubi jalar untuk perlakuan pada tikus yaitu sebesar $0,006 \mathrm{ml} / \mathrm{grBB} /$ hari. $^{18}$

Seluruh tikus ditimbang berat badannya, kemudian diaklimatisasi selama satu minggu, semua kelompok diberi aquadest dan pakan standar. Setelah masa aklimatisasi tikus diambil darahnya untuk dianalisis kadar kolesterol total serum. Kedua kelompok diberi pakan tinggi lemak yaitu pakan standar dan kuning telur melalui sonde selama 14 hari setelah masa aklimatisasi. Kelompok perlakuan dan kontrol kemudian diambil darahnya untuk dianalisis kadar kolesterol total. Selama 14 hari kemudian tikus pada kelompok perlakuan diberi jus daun ubi jalar melalui sonde. Kelompok perlakuan dan kontrol kemudian diambil darahnya untuk dianalisis kadar kolesterol total serum. Sebelum diambil sampel darahnya tikus dipuasakan selama 12 jam, selanjutnya sampel darah diambil sebanyak $2 \mathrm{ml}$ melalui pleksus retroorbitalis. Kadar kolesterol total ditentukan secara enzimatik dengan metode cholesterol oxidase para aminophenazone ; diasys (CHOD-PAP). ${ }^{19}$

Seluruh data yang diperoleh dilakukan uji normalitas dengan uji Saphiro-Wilk. Perbedaan kadar kolesterol total sebelum dan setelah pemberian pakan tinggi lemak menggunakan paired sample t-test dan perbedaan kadar kolesterol total setelah pemberian pakan tinggi lemak dan setelah pemberian daun ubi jalar dengan menggunakan uji Wilcoxon. Perbedaan pengaruh perlakuan kedua kelompok dianalisis dengan menggunakan uji independent sample t-test untuk data berdistribusi normal dan uji Mann-Whitney untuk data berdistribusi tidak normal. ${ }^{20}$

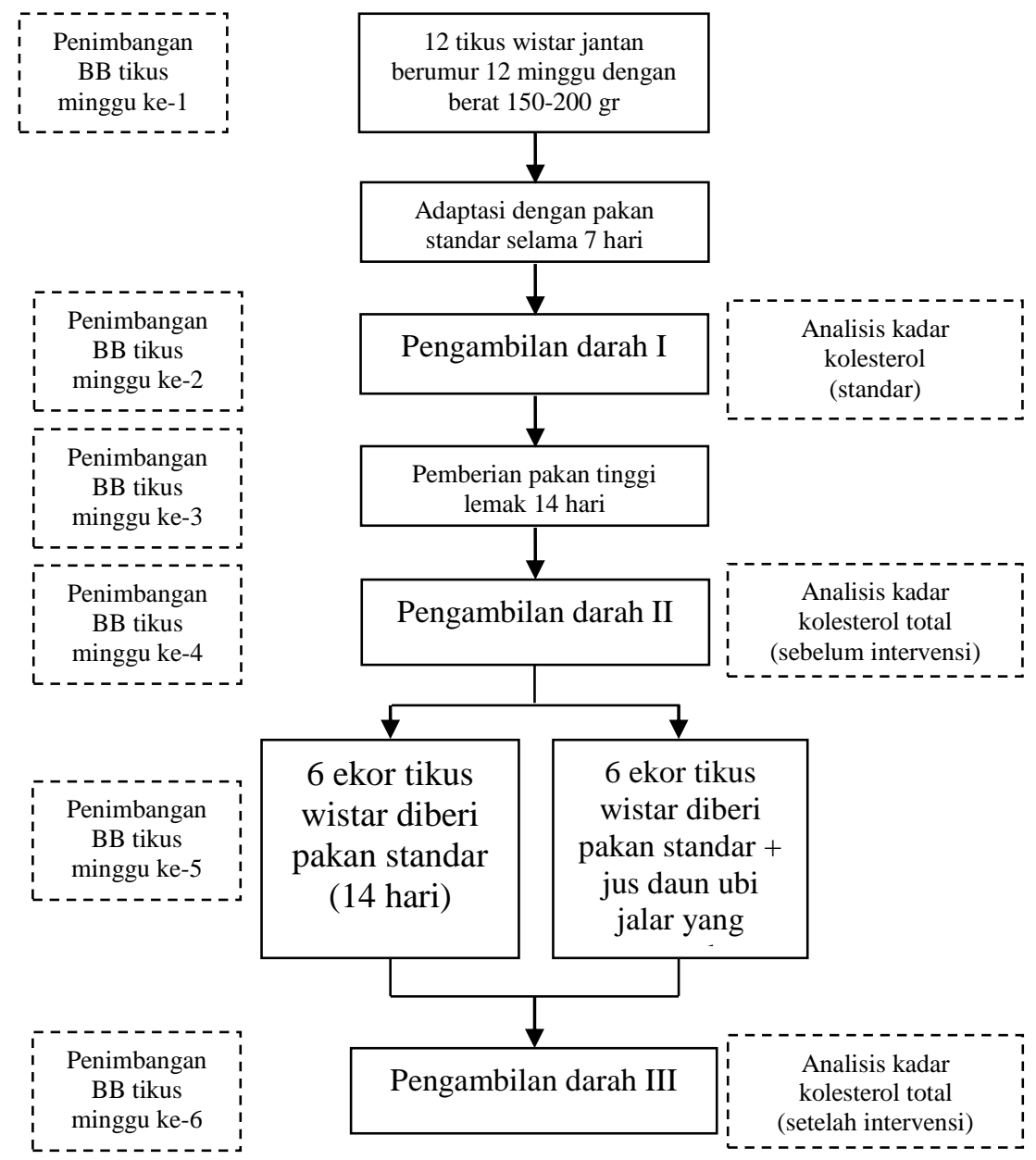

Gambar 1. Bagan Alur Penelitian 
HASIL PENELITIAN

Berat Badan Tikus

Perkembangan berat badan pada tikus wistar jantan (Rattus norvegicus) pada kelompok kontrol dan perlakuan selama penelitian dapat dilihat pada gambar 2 .

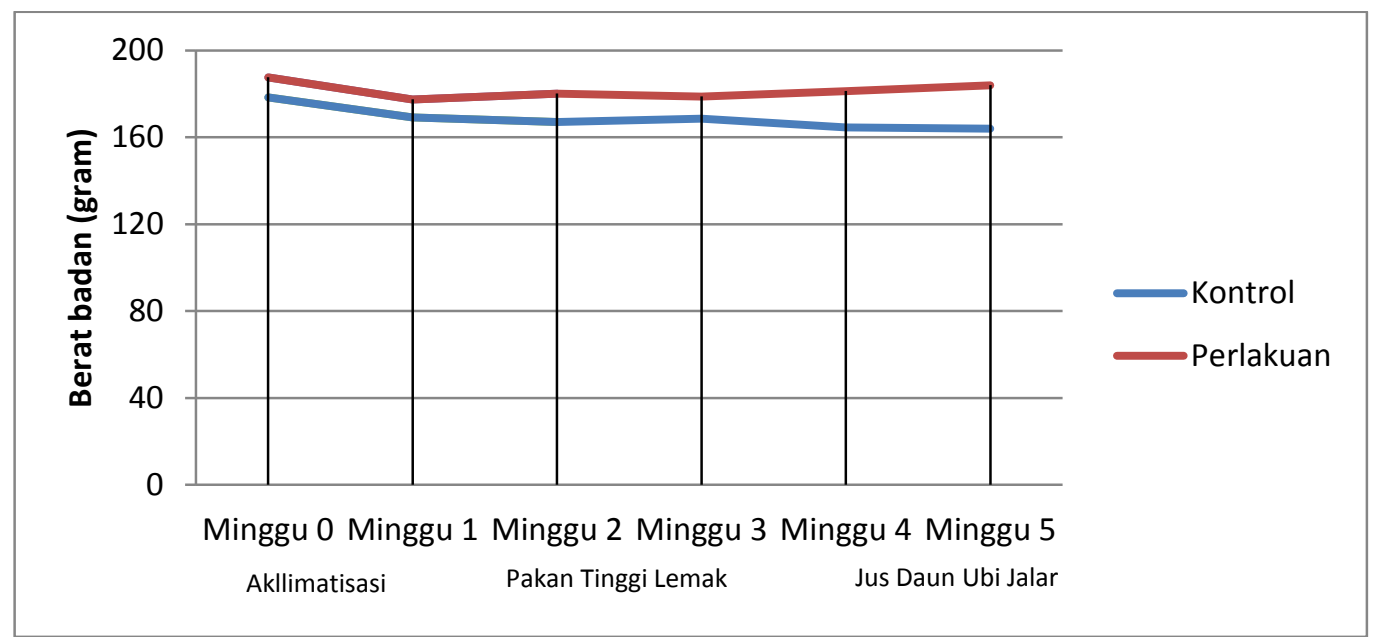

Gambar 2. Perkembangan berat badan tikus wistar jantan

Berat badan pada masing - masing Hasil dari analisis tersebut dapat dilihat pada tabel kelompok sebelum dan sesudah pemberian pakan tinggi lemak dianalisis menggunakan paired t-test. 1.

Tabel 1. Perbedaan berat badan tikus sebelum dan sesudah pemberian pakan tinggi lemak

\begin{tabular}{llll}
\hline \multirow{2}{*}{ Variabel } & Kontrol $(\mathbf{n}=\mathbf{6})$ & Perlakuan $(\mathbf{n}=\mathbf{6})$ & \multirow{2}{*}{$\mathbf{p}^{\mathbf{1}}$} \\
\cline { 2 - 3 } & Mean $\mathbf{S D}$ & Mean \pm SD & \\
\hline Berat Badan $(\mathbf{g})$ & & & \\
Sebelum & $169.17 \pm 6.55$ & $177.50 \pm 7.40$ & 0.382 \\
Sesudah & $167.67 \pm 9.11$ & $178.83 \pm 6.43$ & \\
$\boldsymbol{\Delta}$ & $-0.50 \pm 3.94$ & $1.33 \pm 2.94$ & \\
$\mathbf{P}$ & $0.768 *$ & $0.318 *$ & \\
\hline Keterangan: *Uji paired t-test & 1 Uji beda Independent t-test
\end{tabular}

Tabel 1 menunjukkan bahwa selama 14 hari perlakuan pada kelompok kontrol terdapat penurunan berat badan namun tidak signifikan $(\mathrm{p}<$ 0,05). Hasil pada kelompok perlakuan menunjukkan terdapat peningkatan berat badan tikus namun tidak signifikan $(\mathrm{p}<0,05)$. Perbedaan rerata perubahan berat badan antar kelompok dianalisis menggunakan uji independent t-test, didapatkan hasil bahwa tidak ada perbedaan berat badan antara kelompok kontrol dan kelompok perlakuan yang diberi pakan tinggi lemak.

Berat badan pada masing - masing kelompok sesudah pemberian pakan tinggi lemak dan sesudah pemberian jus daun ubi jalar dianalisis menggunakan paired t-test. Hasil dari analisis tersebut dapat dilihat pada tabel 2 .

Tabel 2. Perbedaan berat badan tikus sesudah pemberian pakan tinggi lemak dan sesudah pemberian jus daun ubi jalar

\begin{tabular}{|c|c|c|c|}
\hline \multirow{2}{*}{ Variabel } & Kontrol $(n=6)$ & Perlakuan $(n=6)$ & \multirow{2}{*}{$\mathbf{p}^{\mathbf{1}}$} \\
\hline & Mean \pm SD & Mean \pm SD & \\
\hline \multicolumn{4}{|l|}{ Berat Badan（g) } \\
\hline Pakan Tinggi Lemak & $167.67 \pm 9.11$ & $178.83 \pm 6.43$ & \\
\hline Jus Daun Ubi Jalar & $164.00 \pm 9.75$ & $184.00 \pm 5.83$ & 0.003 \\
\hline$\Delta$ & $-4.67 \pm 3.56$ & $5.17 \pm 3.76$ & \\
\hline $\mathbf{P}$ & $0.062 *$ & $0.020 *$ & \\
\hline
\end{tabular}


Tabel 2 menunjukkan bahwa selama 14 hari perlakuan pada kelompok kontrol terdapat penurunan berat badan meskipun tidak signifikan ( $\mathrm{p}>0,05)$. Hasil pada kelompok perlakuan menunjukkan terdapat peningkatan berat badan yang signifikan setelah perlakuan jus daun ubi jalar $(\mathrm{p}<0,05)$. Perbedaan rerata perubahan berat badan antar kelompok dianalisis menggunakan uji independent $t$-test, didapatkan hasil bahwa terdapat perbedaan berat badan yang signifikan antara kelompok kontrol dan kelompok perlakuan yang diberi jus daun ubi jalar.

Perubahan Kadar Serum Kolesterol Total Sebelum dan Sesudah Pemberian Pakan Tinggi Lemak

Kadar kolesterol total awal dan sesudah pemberian pakan tinggi lemak masing - masing tikus tiap kelompok dapat dilihat pada tabel 3.

Tabel 3. Kadar kolesterol total awal dan sesudah pemberian pakan tinggi lemak

\begin{tabular}{cccc}
\hline \multirow{2}{*}{ Tikus } & \multicolumn{3}{c}{ Kadar Kolesterol Total } \\
\cline { 2 - 4 } & Awal & Pakan Tinggi Lemak & Keterangan \\
\hline K1 & 67.74 & 64.80 & Turun \\
K2 & 58.21 & 63.57 & Naik \\
K3 & 98.19 & 60.90 & Turun \\
K4 & 46.35 & 65.56 & Naik \\
K5 & 48.71 & 59.92 & Naik \\
K6 & 97.77 & 69.18 & Turun \\
P1 & 97.32 & 56.17 & Turun \\
P2 & 56.89 & 76.70 & Naik \\
P3 & 64.56 & 94.01 & Naik \\
P4 & 43.91 & 64.70 & Naik \\
P5 & 63.54 & 39.23 & Turun \\
P6 & 59.22 & 72.26 & Naik \\
& & & \\
\hline
\end{tabular}

Tabel 3 menunjukkan terjadi peningkatan kadar kolesterol total pada tikus yang diberi perlakuan pakan tinggi lemak sebanyak 7 ekor sedangkan 5 ekor tikus yang lain mengalami penurunan kadar kolesterol total. Rerata kadar kolesterol total serum pada masing - masing kelompok sebelum dan sesudah pemberian pakan tinggi lemak dianalisis menggunakan paired t-test. Hasil dari analisis tersebut dapat dilihat pada tabel 4.

Tabel 4. Perbedaan profil lipid sebelum dan sesudah pemberian pakan tinggi lemak

\begin{tabular}{llll}
\hline \multirow{2}{*}{ Variabel } & Kontrol $(\mathbf{n}=\mathbf{6})$ & \multicolumn{1}{l}{ Perlakuan $(\mathbf{n}=\mathbf{6})$} & \multirow{2}{*}{$\mathbf{p}^{\mathbf{1}}$} \\
\cline { 2 - 3 } & Mean \pm SD & Mean \pm SD & \\
\hline Kadar Kolesterol Total (mg/dl) & & & \\
Sebelum & $69.50 \pm 23.33$ & $64.24 \pm 17.82$ & \\
Sesudah & $63.99 \pm 3.36$ & $67.18 \pm 18.68$ & 0.583 \\
$\boldsymbol{\Delta}$ & $-5.51 \pm 22.62$ & $2.94 \pm 28.62$ & \\
$\mathbf{P}$ & $0.577^{*}$ & $0.811^{*}$ & \\
\hline Keterangan: *Uji paired t-test & 1 Uji beda Independent t-test
\end{tabular}

Tabel 4 menunjukkan bahwa selama 14 hari perlakuan pakan standar pada kelompok kontrol terdapat penurunan kadar kolesterol total namun tidak signifikan $(\mathrm{p}>0,05)$. Hasil pada kelompok perlakuan menunjukkan terdapat peningkatan kadar kolesterol total setelah perlakuan pakan tinggi lemak meskipun tidak signifikan $(\mathrm{p}>0,05)$. Perbedaan rerata perubahan kadar kolesterol total antar kelompok dianalisis menggunakan uji independent t-test, didapatkan hasil bahwa tidak ada perbedaan kadar kolesterol total antara kelompok kontrol dan kelompok perlakuan yang diberi pakan tinggi lemak.

Perubahan Kadar Serum Kolesterol Total Sesudah Pemberian Pakan Tinggi Lemak dan Sesudah Pemberian Jus Daun Ubi Jalar

Kadar kolesterol total sesudah pemberian pakan tinggi lemak dan sesudah pemberian jus daun ubi jalar masing - masing tikus tiap kelompok dapat dilihat pada tabel 5. 
Tabel 5. Kadar kolesterol total sesudah pemberian pakan tinggi lemak dan sesudah pemberian jus daun ubi jalar

\begin{tabular}{cccc}
\hline \multirow{2}{*}{ Tikus } & \multicolumn{3}{c}{ Kadar Kolesterol Total } \\
\cline { 2 - 4 } & Pakan Tinggi Lemak & Jus Daun Ubi Jalar & Keterangan \\
\hline K1 & 64.80 & 62.58 & Turun \\
K2 & 63.57 & 82.91 & Naik \\
K3 & 60.90 & 79.56 & Naik \\
K4 & 65.56 & 71.03 & Naik \\
K5 & 59.92 & 67.29 & Naik \\
K6 & 69.18 & 41.80 & Turun \\
P1 & 56.17 & 66.90 & Naik \\
P2 & 76.70 & 71.73 & Turun \\
P3 & 94.01 & 68.82 & Turun \\
P4 & 64.70 & 75.47 & Naik \\
P5 & 39.23 & 21.38 & Turun \\
P6 & 72.26 & 61.47 & Turun \\
& & & \\
\hline
\end{tabular}

Tabel 5 kelompok kontrol yang hanya diberi pakan standar menunjukkan peningkatan kadar kolesterol total pada 4 ekor tikus sedangkan 2 ekor yang lain mengalami penurunan kadar kolesterol total. Tikus kelompok perlakuan jus daun ubi jalar rata - rata mengalami penurunan kadar kolesterol total yaitu sebanyak 4 ekor tikus, sedangkan 2 ekor yang lain mengalami peningkatan. Rerata kadar kolesterol total serum pada masing - masing kelompok sesudah pemberian pakan tinggi lemak dan sesudah pemberian jus daun ubi jalar dianalisis menggunakan paired t-test pada kelompok kontrol dan uji willcoxon pada kelompok perlakuan. Hasil dari analisis tersebut dapat dilihat pada tabel 6 .

Tabel 6. Perbedaan profil lipid sesudah pemberian pakan tinggi lemak dan sesudah pemberian jus daun ubi jalar

\begin{tabular}{llll}
\hline \multirow{2}{*}{ Variabel } & Kontrol $(\mathbf{n}=\mathbf{6})$ & Perlakuan $(\mathbf{n}=\mathbf{6})$ & \multirow{2}{*}{$\mathbf{p}^{\mathbf{1}}$} \\
\cline { 2 - 3 } & Mean $\mathbf{\text { SD }}$ & Mean \pm SD & \\
\hline Kadar Kolesterol Total (mg/dl) & & $67.18 \pm 18.68$ & \\
Pakan Tinggi Lemak & $63.99 \pm 3.37$ & $60.96 \pm 19.95$ & 0,317 \\
Jus Daun Ubi Jalar & $67.53 \pm 14.70$ & $-6.22 \pm 14.79$ & \\
$\boldsymbol{\Delta}$ & $3.54 \pm 17.24$ & $0,249^{\wedge}$ \\
$\mathbf{P}$ & $0,636^{*}$ & 1 Uji beda independent t-test \\
\hline Keterangan: *Uji paired t-test & ^Uji Willcoxon &
\end{tabular}

Tabel 6 menunjukkan pada kelompok kontrol yang tidak diberi perlakuan apapun selain pakan standar menunjukkan kadar kolesterol total serum terjadi peningkatan meskipun tidak signifikan $(\mathrm{p}>0,05)$. Hasil analisis pada kelompok perlakuan sesudah pemberian intervensi jus daun ubi jalar menunjukkan penurunan kadar kolesterol total serum secara tidak signifikan ( $\mathrm{p}>0,05)$. Perbedaan rerata perubahan kadar kolesterol total antar kelompok dianalisis menggunakan uji beda independent t-test, didapatkan hasil bahwa tidak ada perbedaan kadar kolesterol total antara kelompok kontrol dan kelompok perlakuan.

\section{PEMBAHASAN}

\section{Berat Badan Subjek}

Penimbangan berat badan dilakukan setiap minggu sekali dengan tujuan untuk menilai keseragaman berat badan, status gizi, dan kemungkinan adanya penyakit pada tikus wistar selama penelitian. ${ }^{21}$ Berat badan yang diukur juga digunakan untuk penentuan dosis dalam pemberian pakan dan jus daun ubi jalar. Rerata berat badan kelompok kontrol selama 28 hari intervensi mengalami penurunan. Penurunan berat badan dapat dimungkinkan hewan uji mengalami stres. Penurunan berat badan sejalan dengan peningkatan kadar hormon kortikosteron yang menginduksi pengubahan cadangan glukosa dan lemak untuk penyediaan sumber energi metabolisme yang digunakan dalam merespon stres sehingga terjadilah penurunan berat badan pada tikus. ${ }^{22}$

Rerata berat badan kelompok perlakuan setelah pemberian pakan tinggi lemak mengalami peningkatan. Hal ini sesuai dengan penelitian yang menyatakan bahwa pemberian pakan tinggi lemak dapat meningkatkan perkembangan berat badan tikus. ${ }^{23}$ Rerata berat badan sesudah pemberian jus 
daun ubi jalar juga mengalami peningkatan yang signifikan. Hal ini dapat diduga bahwa untuk menurunkan berat badan diperlukan intervensi jus daun ubi jalar dalam jangka waktu yang lebih lama. Selain itu daun ubi jalar mengandung protein yang cukup tinggi. Berdasarkan penelitian kandungan protein daun ubi jalar lebih tinggi dibanding bagian umbi dan akarnya. Protein diperlukan untuk pertumbuhan dan perkembangan manusia dan hewan sehingga dimungkinkan dapat meningkatkan status gizi tikus dalam penelitian ini. $^{24}$

\section{Kadar Serum Kolesterol Total Sesudah Pemberian Pakan Tinggi Lemak}

Pemberian pakan tinggi lemak menggunakan kuning telur bebek sebanyak $2 \mathrm{ml} /$ $200 \mathrm{~g} \mathrm{BB} /$ hari. Kuning telur bebek mengandung 17 gram protein, 35 gram lemak, dan kolesterol 884 $\mathrm{mg} / 100$ gram sehingga diharapkan mampu meningkatkan kadar kolesterol total. ${ }^{25}$ Berdasarkan penelitian, pemberian kuning telur bebek sebanyak 2 gram/200 gram BB tikus wistar dapat menaikkan kadar kolesterol. ${ }^{26}$ Kolesterol secara normal diproduksi oleh tubuh dalam jumlah yang sesuai. Pola makan yang cenderung tinggi lemak dapat menyebabkan kolesterol dalam jumlah berlebihan dalam darah. ${ }^{27}$

Tabel 3 menunjukkan sebanyak 7 ekor tikus yaitu K2, K4, K5, P2, P3, P4, dan P6 mengalami peningkatan kadar kolesterol total. Penelitian sebelumnya menyatakan kuning telur dapat meningkatkan kadar kolesterol total darah tikus. ${ }^{26}$ Keadaan ini terjadi akibat peningkatan penimbunan lemak dalam hepar yang menimbulkan peningkatan jumlah asetil KoA dalam sel hepar untuk menghasilkan kolesterol. Kuning telur mengandung kuning telur bebek yang mengandung 17 gram protein, 35 gram lemak, 884 $\mathrm{mg} / 100$ gr kolesterol selain itu kuning telur mengandung lemak jenuh, lemak jenuh merupakan prekusor kolesterol. Konsumsi lemak jenuh menyebabkan peningkatan kadar kolesterol total sehingga dapat mengakibatkan peningkatan perbandingan kadar kolesterol total dengan HDL yang merupakan pencetus terjadinya aterosklerosis..$^{15,28}$

Tabel 3 juga menunjukkan dari 12 tikus yang diberi pakan tinggi lemak terdapat 5 ekor tikus yaitu K1, K3, K6, P1, dan P5 yang mengalami penurunan kadar kolesterol. Hal ini dapat disebabkan oleh kurangnya waktu intervensi pemberian pakan tinggi lemak yang hanya 14 hari sehingga menyebabkan pemberian kuning telur kurang efektif dalam meningkatkan kadar kolesterol. Berdasarkan penelitian, perlu waktu empat hingga delapan minggu intervensi pemberian kuning telur agar kadar kolesterol total tikus dapat naik secara signifikan. ${ }^{29}$ Pemberian pakan tinggi lemak hanya dilakukan dua minggu karena pertimbangan bahwa pemberian pakan tinggi lemak dalam jangka waktu lama dapat menyebabkan kematian karena keracunan kolesterol akut. ${ }^{30}$

Tabel 4 pada rerata perlakuan pakan tinggi lemak, kadar kolesterol total pada kelompok kontrol mengalami penurunan sebesar $5,51 \mathrm{mg} / \mathrm{dl}$ sedangkan pada kelompok perlakuan kadar kolesterol total meningkat sebesar $2,94 \mathrm{mg} / \mathrm{dl}$ sesudah pemberian pakan tinggi lemak. Ketidakseragaman hasil kadar kolesterol total sesudah intervensi pakan tinggi lemak yang diperoleh kemungkinan dipengaruhi oleh berbagai faktor seperti kondisi biologis, metabolisme tubuh, serta perlakuan dari masing - masing tikus yang berbeda satu sama lain. ${ }^{31}$

\section{Kadar Serum Kolesterol Total Sesudah Pemberian Jus Daun Ubi Jalar}

Rerata kadar kolesterol total pada kelompok kontrol meningkat sebesar 3,54 mg/dl, terdapat 5 ekor tikus pada kelompok kontrol yang mengalami peningkatan berat badan yaitu K2, K3, $\mathrm{K} 4$, dan K5. Kelompok perlakuan juga terdapat 2 ekor tikus mengalami peningkatan kadar kolesterol total yaitu P1 dan P3. Hasil uji laboratorium kadar kolesterol total diduga dapat dipengaruhi oleh lama waktu penyimpanan sehingga banyak sel - sel darah yang lisis. Kesalahan teknis pada saat membawa sampel dari tempat penyimpanan ke tempat pengujian, cara pengambilan darah yang kurang tepat, cara memasukkan sampel darah ke dalam tabung koleksi yang kurang tepat juga dapat berpengaruh terhadap kadar kolesterol total serum. $^{32}$

Tabel 5 pada kelompok kontrol menunjukkan sebanyak 2 ekor tikus yaitu K1 dan K6 mengalami penurunan kadar kolesterol total. Hal ini disebabkan kandungan lemak jenuh dalam pakan standar lebih rendah dibandingkan dengan pakan tinggi lemak. Tabel 5 kelompok perlakuan menunjukkan sebanyak 4 ekor tikus yaitu P2, P3, P5, dan P6 mengalami penurunan kadar kolesterol total. Rerata kadar kolesterol total kelompok perlakuan jus daun ubi jalar menunjukkan terdapat penurunan kadar kolesterol total sebesar 6,22 $\mathrm{mg} / \mathrm{dl}$ meskipun penurunan tersebut tidak signifikan. Hal ini mungkin disebabkan oleh kurangnya waktu intervensi jus daun ubi jalar sehingga antioksidan dan serat yang terkandung dalam daun ubi jalar tidak dapat mengikat semua kolesterol dan lemak dalam usus. Akibatnya 
kolesterol dan lemak dapat diserap oleh alat pencernaan hewan uji. ${ }^{33}$

Berdasarkan literatur daun ubi jalar mengandung berbagai macam zat yang dapat menurunkan kadar kolesterol total darah. Flavonoid yang terkandung dalam daun ubi jalar, terkhususnya quercetin dapat menurunkan kadar kolesterol darah dengan cara meningkatkan ekskresi asam empedu. ${ }^{34}$ Flavonoid mengurangi sintesis kolesterol dengan cara menghambat aktivitas enzim acyl-CoA cholesterol acyl transferase (ACAT) pada sel HepG2 yang berperan dalam penurunan esterifikasi kolesterol pada usus dan hati, serta menghambat aktivitas enzim 3-hiroksi-3metil-glutaril-CoA yang menyebabkan penghambatan sintesis kolesterol. ${ }^{35}$ Quercetin dapat menurunkan kadar kolesterol total dan kadar kolesterol LDL dengan cara menghambat sekresi apolipoprotein B pada sel CaCo-2 dan menurunkan aktivitas microsomal triglyceride transfer protein (MTP) yang memiliki peran dalam pembentukkan lipoprotein dan mengkatalisa perpindahan lipid ke molekul APO B. Penelitian lain juga menyebutkan bahwa quercetin dapat menghambat aktivitas enzim HMG-KoA reduktase, yaitu enzim yang berperan dalam pembentukkan kolesterol. ${ }^{34}$

Daun ubi jalar mengandung polifenol yang berfungsi sebagai antioksidan yang menghambat mekanisme oksidasi. ${ }^{36}$ Polifenol menurunkan absorbsi kolesterol dengan cara berikatan pada cholesterol carriers saat melewati membran brush border. Mekanisme polifenol dalam menurunkan kadar kolesterol lainnya adalah dengan penurunan sekresi apoB yang menyebabkan penurunan lipoprotein. ${ }^{30}$ Tanin dalam daun ubi jalar juga berfungsi sebagai antioksidan, astringent, dan hipokolesterolemia. Tanin bekerja dengan cara bereaksi dengan protein mukosa dan sel epitel usus sehingga menghambat penyerapan. ${ }^{35}$ Tanin mampu mencegah peningkatan kadar kolesterol total melalui mekanisme antioksidan yaitu mencegah terjadinya stress oksidatif dengan menghambat oksidasi LDL. ${ }^{34}$

Daun ubi jalar juga kaya akan serat. Kandungan serat dalam daun ubi jalar bermanfaat untuk menghambat absorbsi kolesterol di usus sehingga berpotensi menurunkan kadar kolesterol. Asupan serat dapat menurunkan kadar kolesterol dengan cara meningkatkan pengeluaran cairan empedu lalu diekskresikan bersama feses. Selain itu bakteri di dalam usus memfermentasi serat untuk memproduksi asam asetat propionat dan butirat yang berfungsi untuk menghambat sintesis kolesterol. ${ }^{37}$

\section{SIMPULAN DAN SARAN}

Jus daun ubi jalar sebanyak $0.006 \mathrm{ml} / \mathrm{g}$ $\mathrm{BB} /$ hari dengan pemberian selama 14 hari tidak dapat menurunkan kadar kolesterol total serum pada tikus kelompok perlakuan. Perlu penelitian lebih lanjut mengenai pemberian jus daun ubi jalar agar dapat menurunkan kadar kolesterol total serum secara signifikan dan perlu melakukan uji kandungan zat gizi, zat antinutisi, dan kandungan fitokimia dalam daun ubi jalar serta kadar lemak dalam kuning telur bebek.

\section{DAFTAR PUSTAKA}

1. Dibyantini RE dan Irwan S. Uji Efektifitas Ekstrak Kelopak Rosella (Hibiscus sabdariffa L.) terhadap Penurunan Kadar Kolesterol Serum Darah Ayam Broiler. Unimed. 2011.

2. Stapleton Phoebe A, Adam GG, Milinda EJ, Robert WB, dan Jefferson CF. Hypercholesterolemia and Microvascular Dysfunction : Interventional Strategies. Journal of Inflamation 2010; 7: 54.

3. World Health Organization. Global status report on noncommunicable disease 2010. Geneva, 2011.

4. Kementrian Kesehatan Republik Indonesia. Riset Kesehatan Dasar 2007. Badan Penelitian dan Pengembangan Kesehatan Kementerian Kesehatan Republik Indonesia. Jakarta, 2007.

5. Kementrian Kesehatan Republik Indonesia. Riset Kesehatan Dasar 2007. Badan Penelitian dan Pengembangan Kesehatan Kementerian Kesehatan Republik Indonesia. Jakarta, 2007.

6. L Jimaima, VC Trrenerry. Mark W, Robert P. Phytochemical Flavonols, Carotenoids and The Antioxidant Properties of a Wide Selection of Fijian Fruit, Vegetables and Other Readily Available Foods. Asia Pacific Health and Nutrition Centre; 2005.

7. Sukma. Pengaruh Pemberian Seduhan Kelopak Kering Rosella Ungu (Hibiscus sabdariffa) terhadap Kadar Kolesterol LDL Serum Tikus Wistar Hiperkolesterolemik. Universitas Diponegoro; 2011

8. Nurdiana, Subandi, dan Bithonah AP. Efek Analgesik Ekstrak Daun Ubi Jalar (Lpomoea batatas L) pada Tikus (Rattus Norvegicus) Strain Wistar. Universitas Brawijaya; 2012.

9. Islam Shahidul. Nutritional and Medicinal Qualities of Sweetpotato Tops and Leaves. University of Arkansas at Pine Bluff; 2007.

10. Zern Tosca L dan Maria LF. Recent Advances in Nutritional Sciences : Cardioprotective Effect of Dietary Polyphenols. Journal of Nutrition 2005:2291-4.

11. Sumardika IW dan I Made Jawi. Ekstrak Air Daun Ubi Jalar Ungu Mempebaiki Profil Lipid dan Meningkatkan Kadar SOD Darah Tikus yang 
Diberi Makanan Tinggi Kolesterol. Jurnal Ilmiah Keedokteran Mediciana. 2012;43:67-71.

12. Li Fenglin, Qingwang Li, Dawai Gao, dan Yong Pen. The Optimal Extraction Parameters and AntiDiabetic Activity of Flavonoids from Ipomoea Batatas Leaf. Afr J Tradit Complement Altern Med, 2009:6(2):195-202.

13. World Health Organization (WHO). General Guidelinesfor Methodologies on Research and Evaluation of Traditional Medicine. Geneva: WHO; 2001.

14. Riyantie, Novie. Pengaruh Defisiensi Pakan terhadap Perubahan Beberapa Berat Organ Tikus Betina Dewasa (Rattus sp.). Bagian Fisiologi dan Farmakologi. Fakultas Kedokteran Hewan. Institut Pertanian Bogor. 2001.

15. Sumber data: Badan Ketahanan Pangan dan Penyuluhan Provinsi DIY

16. Kahono JY. Pengaruh Ekstrak Herba Meniran (Phyllantus niruri L.) terhadap Kadar Trigliserida Darah Tikus Putih (Rattus norvegicus). Universitas Sebelas Maret. 2010

17. Yuliani Dwi, Nurdiana, dan Yulian Wiji Utami. Pengaruh Pemberian Jus Brokoli (Brassica oleracea L. var. Italica) terhadap Penurunan Kadar Glukosa Darah Tikus Putih (Rattus norvegicus strain wistar) Model Diabetes Mellitus. Universitas Brawijaya. 2013.

18. Ghasemzadeh Ali, Hawa ZEJ, dan Asmah R. Antioxidant Activities, Total Phenolics and Flavonoids Content in Two Varieties of Malaysia Young Ginger (Zingiber officinale Roscoe). Molecules; 2010; 15: 4324-33.

19. N.S. Bio-Tec. Cholesterol (CHOD-PAP) :

Enzymatic Colorimetric Determination of Serum Cholesterol. Available from URL : www.nsbiotec.com/chol.pdf.

20. Dahlan MS. Statistik untuk Kedokteran dan Kesehatan. Salemba Medika. Jakarta: 2011.

21. Wibowo, Trimanto. Pengaruh Pemberian Seduhan Kelopak Rosella (Hibiscus sabdariffa) terhadap Kadar Trigliserida Darah Tikus Putih (Rattus norvegicus). Universitas Sebelas Maret. 2009.

22. Ridwan Ahmad, Zuliyanto Zakaria, dan Anggraini Barlian. Pengaruh Fotoperiode terhadap Respons Stres dan Parameter Repoduksi pada Mencit Jantan (Mus musculus L.) Galur Wistar Webster. Jurnal Matematika dan Sains, 2012:17(1).

23. Fatimah Feni dan Barlina Rindengan. Pengaruh Diet Emulsi Virgin Coconut Oil (VCO) terhadap Profil Lipid Tikus Putih (Rattus norvegicus).Jurnal Litri, 2011:17(1);18-24.

24. Asmara IY, D Garnida, dan W Tanwariah. Penampilan Broiler yang Diberi Ransum Mengandung Tepung Daun Ubi Jalar (Ipomoea batatas) terhadap Karakteristik Karkas. Universitas Padjajaran Bandung. 2007.

25. Novi Cynthia PD. Pengaruh Pemberian Ekstrak Kacang Hijau (Phaseolus radiates) terhadap Kadar
Kolesterol LDL Serum Tikus Hiperkolesterolemia. Universitas Diponegoro. 2013.

26. Judo Yustanto Kahono. Pengaruh Ekstrak Herba Meniran (Phyllantus niruri L.) terhadap Kadar Trigliserida Darah Tikus Putih (Rattus norvegicus). Universitas Sebelas Maret 2010.

27. Ni Putu Ariantari, Sagung Chandra Yowani, dan Dewa Ayu Swastini. Uji Aktivitas Penurunan Kolesterol Produk Madu Herbal yang Beredar di Pasaran pada Tikus Putih Diet Lemak Tinggi. Universitas Udayana. Jurnal Kimia Januari 2010, 4(1);15-9.

28. Harini Marti. Kadar Kolesterol Darah Ekspresi VCZM-1 pada Endotel Aorta Tikus Putih (Rattus norvegicus L) Hiperkolesterolemik setelah Perlakuan VCO. Universitas Sebelas Maret Surakarta, 2009.

29. Dwiloka Bambang. Efek Kolesterolemi Berbagai Telur. Media Gizi \& Keluarga, 2003, 27(2):58-65.

30. Hakim RD. Pengaruh Pemberian Ekstrak Bawang Merah terhadap Kadar Kolesterol LDL Serum Tikus Wistar Jantan Hiperlipidemia. Universitas Diponegoro, 2009.

31. Widyaningsih Wahyu. Efek Ekstrak Etanol Rimpang Temugiring (Curcuma heyneana val) terhadap Kadar Trigliserida. Jurnal Ilmiah Kefarmasian, 2011:1(1);55-65.

32. Harahap Dianatul Habibah, Yudha Fahrimal, dan Hamdani Budiman. Gambaran Darah Tikus yang diinfeksikan Trypanosoma evansi dan diberi Ekstrak Daun Sernai (Wedelia biflora). Jurnal Medika veterinaria, 2013:7(2);126-9.

33. Juheni. Pemanfaatan Herba Seledri (Apium graveolens L.) untuk menurunkan Kolesterol dan Lipid dalam Darah Tikus Putih yang diberi Diit Tinggi Kolesterol dan Lemak. Makara. Sains, 2002:6(2);65-9.

34. Perdido. Efek Pemberian Jus Advokad (Persea Americanana P.Mill) terhadap Kadar Kolesterol HDL dan LDL pada Tikus Putih (Rattus Norvegicus). Universitas Sebelas Maret. Surakarta; 2011.

35. Arief, Iqbal, Riky Novriansyah, Indra Tjeng Budianto, dan Muhammad Bimo Harmaji. Potensi Bunga Karamunting (Melastoma malabathricum L.) terhadap Kadar Kolesterol Total dan Trigliserida pada Tikus Putih Jantan yang diinduksi Propiltiourasil. Prestasi 2012;1(2).

36. Umarudin, R. Susanti, dan Ari Yuniastuti. Efektivitas Ekstrak Tanin Seledri Terhadap Profil Hiperkolesterolemi Lipid Tikus Putih. Journal of Life Science 2012;1(2).

37. Rahmawati, Ayu C, Siti Z, dan Setyaningrum R. Aktivitas Fisik dan Rasio Kolesterol (HDL) pada Penderita Penyakit Jantung Koroner di Poliklinik Jantung RSUD DR Moewardi Surakarta. Jurnal Kesehatan 2009;2(1):11-8. 